\title{
Purification and properties of an extracellular aminopeptidase from Streptomyces lividans 1326
}

\author{
Jayant S. Aphale $\dagger$ and William R. Strohl* \\ Department of Microbiology, The Ohio State University, 484 West 12th Avenue, Columbus, Ohio 43210, USA
}

(Received 4 September 1992; revised 19 October 1992; accepted 26 October 1992)

\begin{abstract}
Streptomyces lividans was investigated for extracellular proteinases. The major extracellular proteinase activity detected under all conditions tested was L-leucine aminopeptidase activity. Slight extracellular L-proline aminopeptidase activity was also detected. No clear evidence for the presence of serine proteinases in $\boldsymbol{S}$. lividans culture broths was found using several different methods. The major extracellular proteinase of $S$. lividans, i.e. the L-leucine aminopeptidase, was purified 33-fold to homogeneity. The purified enzyme was found by SDS-PAGE to have an $M_{\mathrm{r}}$ of 34000 . The purified enzyme had a final specific activity of 3.6 units $\mathrm{mg}^{-1}$, a $K_{\mathrm{m}}$ for L-leucine-pnitroanilide of $300 \mu \mathrm{M}$ and a $V_{\max }$ of $4.2 \mu \mathrm{mol} \mathrm{min}-1 \mathrm{mg}^{-1}$. The pure enzyme did not exhibit proteolytic activity on azocasein or L-proline-p-nitroanilide, substrates for other proteinase activities observed in crude extracts of $S$. lividans.
\end{abstract}

\section{Introduction}

There has been significant interest in the use of Streptomyces lividans, the primary streptomycete recombinant DNA host strain, as a host strain for secretion of heterologous recombinant proteins into the culture broth (Lichenstein et al., 1988; Taguchi et al., 1989; Bender et al., 1990; Malek et al., 1990). Thus, it is important to elucidate the complement of extracellular proteinases which may degrade potentially valuable secreted recombinant products produced in fermentations with this strain. Aretz et al. (1989) indicated that $S$. lividans contains both aminopeptidase and chymotrypsin-like serine proteinase activities. Their data suggested that the

\footnotetext{
*Author for correspondence. Tel. (614) 292-1919; fax (614) 2921538; e-mail:wstrohl@magnus.acs.ohio-state.edu.

$\dagger$ Present address: Cangene Corporation, Mississauga, Ontario, Canada L4V 1T4.

Abbreviations: ala-pNA, L-alanine-p-nitroanilide; BAPNA, $N-\alpha$ benzoyl-L-arginine p-nitroanilide; CBZ-GGL-pNA, carbobenzoxyglycyl-glycyl-leucine $p$-nitroanilide; N-CBZ-PLG-hydroxamate, $N$ carbobenzoxy-prolyl-leucyl-glycine hydroxamate; DIFP, diisopropylfluorophosphate; FAGLA, $N$-[3-(2-furyl)acryloyl]-glycyl-leucine amide; FALGPA, $N$-[3-(2-furyl)acryloyl]-leucyl-glycyl-prolyl-alanine; gly-pNA, L-glycine-p-nitroanilide; LAP, L-leucine aminopeptidase; leu-pNA, L-leucine-p-nitroanilide; lys-pNA, L-lysine-p-nitroanilide; NTA, nitrilotriacetic acid; SAAPF-pNA, $N$-succinyl-alanyl-alanylprolyl-phenylalanine $p$-nitroanilide; TAME, $N$ - $\alpha$-p-tosyl-L-arginine methyl ester.
}

serine proteinase activity is strong rather than weak (Aretz et al., 1989). We have also previously noted that $S$. lividans contains a significant proteolytic activity against azocasein, although the source of that activity was not characterized (Gibb et al., 1989).

In a recent investigation of a recombinant neutral proteinase from Streptomyces sp. C5 expressed in $S$. lividans, we noticed that the major extracellular proteinase activity contributed by the host strain, $S$. lividans 1326, was an aminopeptidase (Lampel et al., 1992). Thus, we have examined $S$. lividans for its extracellular proteinase activities, and have purified and characterized the major extracellular proteinase of $S$. lividans, a leucine aminopeptidase (LAP; EC 3.4.11.-).

\section{Methods}

Organisms and fermentation conditions. The strain used in this study, S. lividans 66 (John Innes strain 1326), was obtained from D. A. Hopwood (John Innes, Norwich, UK). This strain has been maintained on TSA (trypticase soy agar; Becton Dickinson) plates. For inoculum preparation, spores were aseptically scraped from a TSA plate and inoculated into a $250 \mathrm{ml}$ flask containing $50 \mathrm{ml}$ of MB (milk broth) medium, which contained $\left(\mathrm{g}^{-1}\right)$ : MOPS buffer, 1.49; Nutrient Broth (Difco), $1.0 ; \mathrm{CaCl}_{2} .2 \mathrm{H}_{2} \mathrm{O}, 0.735 ; \mathrm{KH}_{2} \mathrm{PO}_{4}, 0.5 ; \mathrm{K}_{2} \mathrm{HPO}_{4}, 0.5$; and fructose, 0.25 . The $\mathrm{pH}$ was adjusted to 7.2 with $1 \mathrm{M}-\mathrm{NaOH}$ prior to autoclaving. Powdered dry milk (Carnation Co.) was autoclaved separately as a $20 \%(\mathrm{w} / \mathrm{v})$ solution in double-distilled water and added to the medium after cooling to make a final concentration of $20 \mathrm{~g} \mathrm{l}^{-1}$. Conditions used for growth and analysis of the primary and secondary seed cultures and 10 litre fermentation cultures of $S$. lividans are described elsewhere (Lampel et al., 1992). 
Proteinase assays and protein determination. LAP activity in cell-free fermentation broth was determined by monitoring the release of $p$-nitroaniline $\left(\varepsilon_{410}=8480 \mathrm{l} \mathrm{mol}^{-1} \mathrm{~cm}^{-1}\right.$; Vinci, 1988) from leu-pNA at $410 \mathrm{~nm}$ using a single-beam spectrophotometer (Beckman model DU64). Fermentation samples $(500 \mu l)$ collected at time intervals were centrifuged at 10000 r.p.m. for $10 \mathrm{~min}$ in a microcentrifuge to pellet the mycelia. A $100 \mu \mathrm{l}$ sample of the supernatant was added to $880 \mu \mathrm{l}$ of a buffer which was composed of 100 mM-HEPES (pH 8.0), $10 \mathrm{~mm}-\mathrm{MgCl}_{2}$ and $10 \mathrm{mM}-\mathrm{CaCl}_{2}$ (HCM buffer), and held at $37^{\circ} \mathrm{C}$ for $15 \mathrm{~min}$. A resulting uncharacterized precipitate was removed by centrifugation at 10000 r.p.m. for $15 \mathrm{~min}$ in a microcentrifuge. To the clarified cell free broth, $20 \mu \mathrm{l}$ of a $100 \mathrm{~mm}$-solution of leu-pNA in $95 \%$ (v/v) ethanol was added to begin the assay, which was carried out at ambient temperature (about $22^{\circ} \mathrm{C}$ ).

The following $p$-nitroanilide proteinase substrates were also assayed in HCM buffer as described above: SAAPF-pNA, a substrate for chymotrypsin-like proteinases (Delmar et al., 1979); BAPNA, a substrate for trypsin-like proteinases (Erlanger et al., 1961); and other potential aminopeptidase substrates, ala-pNA, gly-pNA, lys-pNA and pro-pNA. Stock solutions of $5.0 \mathrm{~mm}$ were used for each synthetic substrate to yield a final concentration in the assay of $0.25 \mathrm{~mm}$. LeupNA was dissolved in $95 \%$ ethanol, BAPNA was dissolved in DMSO, and SAAPF-pNA was dissolved in 100 mM-HEPES buffer ( $\mathrm{pH} 7 \cdot 0$ ).

Thermolysin-like neutral proteinase activity was measured by the hydrolysis of FAGLA as described by Feder (1968) and esterase activity was assayed by the hydrolysis of TAME as described by Roberts \& Elmore (1974). The enzymic hydrolysis of azocasein was assayed as described previously (Gibb et al., 1989). The milk hydrolysis activity of the proteinase was determined by the spectrophotometric assay described by Lampel $e t$ al. (1992).

Proteinase assays were also performed on cell extracts of $S$. lividans obtained after breakage. Mycelia from $300 \mathrm{ml}$ of fermentation broth were harvested by centrifugation at $16000 \mathrm{~g}$ for $15 \mathrm{~min}$ at $4{ }^{\circ} \mathrm{C}$. The mycelial pellet was rinsed once with ice-cold HCM buffer and resuspended in $5 \mathrm{ml}$ of the same buffer. The resuspended mycelia were disrupted in a French pressure cell (American Instrument Co.) at $16000 \mathrm{lbf}^{-2}$ (about $110 \mathrm{MPa}$ ). Unbroken mycelia and cellular debris were pelleted by centrifugation at $20000 \mathrm{~g}$ for $30 \mathrm{~min}\left(4^{\circ} \mathrm{C}\right)$ and the supernatant was used for intracellular proteinase assays. Protein concentration was determined by the dye-binding method of Bradford (1976) using a commercial protein assay reagent (Bio-Rad) and bovine serum albumin as the standard.

Electrophoresis procedures. SDS-PAGE was carried out as described by Lampel et al. (1992). Proteins in the gels were fixed with $50 \%$ (v/v) methanol for $2 \mathrm{~h}$ and stained with $2 \%(\mathrm{w} / \mathrm{v})$ Coomassie brilliant blue$\mathrm{R}$ for $2 \mathrm{~h}$. The gels were destained for $2 \mathrm{~h}$ by diffusion into an aqueous solution of $7.5 \%(\mathrm{v} / \mathrm{v})$ acetic acid and $50 \%(\mathrm{v} / \mathrm{v})$ methanol.

$\left[{ }^{3} H\right] D I F P$-binding assay. The presence of serine proteinases in the culture broths of $S$. lividans 1326 and other streptomycetes, grown in GYE medium (Gibb et al., 1989), was determined by [ $\left.{ }^{3} \mathrm{H}\right] \mathrm{DIFP}$ binding for $30 \mathrm{~min}$ at $37^{\circ} \mathrm{C}$ using the procedure described by Coletta \& Miller (1986). $\left[{ }^{3} \mathrm{H}\right] \mathrm{DIFP}$ [Dupont-NEN; $4 \cdot 4 \mathrm{Ci} \mathrm{mmol}^{-1}, 1 \mu \mathrm{Ci} \mathrm{ll}^{-1}$ (163 GBq$\left.\left.\mathrm{mmol}^{-1}, 37 \mathrm{kBq} \mathrm{\mu l}^{-1}\right)\right]$ was added to each sample to achieve a final concentration of $100 \mu \mathrm{M}$ and the solutions were incubated for $30 \mathrm{~min}$ at $37^{\circ} \mathrm{C}$. After incubation, the proteins were precipitated with ice-cold $10 \%(\mathrm{w} / \mathrm{v})$ TCA for $20 \mathrm{~min}$. The precipitated proteins were recovered by centrifugation in a microcentrifuge at 10000 r.p.m. for $15 \mathrm{~min}$ and dried under vacuum. The precipitate was then resuspended in $14 \mu \mathrm{l}$ of sample buffer and the proteins were separated by SDS-PAGE according to Dreyfuss et al. (1984). The gels were dehydrated by soaking them twice for $20 \mathrm{~min}$ each in $20 \mathrm{vols}$ DMSO, after which they were impregnated with PPO by immersion for $1 \mathrm{~h}$ in 4 vols $22.2 \%(\mathrm{w} / \mathrm{v})$ PPO in DMSO. Excess PPO in the gel was precipitated in situ by soaking the gels for $1 \mathrm{~h}$ in double-distilled water. The PPO-impregnated gel was then dried under vacuum for $1 \mathrm{~h}$ using a mini slab gel drier (Hoefer Scientific Instruments). The DIFP-binding proteins in the gel were visualized by autoradiography for 48 to $72 \mathrm{~h}$ on X-ray film (Kodak XAR).

Purification of S. lividans LAP. Mycelia from 3 litres of culture broth were harvested after $120 \mathrm{~h}$ of fermentation by tangential flow filtration using a Pellicon filtration system (Millipore) equipped with $0.45 \mu \mathrm{m}$ membranes $\left(2 \mathrm{ft}^{2}\right.$ of membrane area). The cell-free culture broth (2800 ml) was chilled to $4{ }^{\circ} \mathrm{C}$ by holding on ice and was concentrated to $200 \mathrm{ml}$ using the Pellicon filtration unit equipped with an $M_{\mathrm{r}} 10000$ cut-off membrane ( $5 \mathrm{ft}^{2}$ of membrane area). The retentate, which contained all the LAP activity, was used for further purification work and was lyophilized and stored as a powder at $-20^{\circ} \mathrm{C}$ when not in use.

A pre-packed Pharmacia Superose-6 FPLC column (HR 10/30) equilibrated with $50 \mathrm{~mm}-\mathrm{Tris} / \mathrm{HCl}(\mathrm{pH} 6.5)$ containing $150 \mathrm{~mm}-\mathrm{NaCl}$ was used for gel-filtration chromatography. Approximately $700 \mu \mathrm{g}$ of protein were loaded onto the matrix. The flow rate of buffer was $0.5 \mathrm{ml} \mathrm{min}{ }^{-1}$ and $250 \mu \mathrm{l}$ fractions were collected for analysis. Ionexchange chromatography was performed using prepacked Mono-Q FPLC columns (HR 10/10, $1 \times 10 \mathrm{~cm}$; HR $5 / 5,0.5 \times 5 \mathrm{~cm}$ ), preequilibrated with 5 vols $20 \mathrm{~mm}$-Tris/ $\mathrm{HCl}(\mathrm{pH} 8 \cdot 0)$, on a Pharmacia FPLC apparatus. The flow rate was adjusted to $1 \mathrm{ml} \mathrm{min}^{-1}$ and bound proteins were eluted from the resin by application of a linear 0 to $1.0 \mathrm{M}-$ $\mathrm{NaCl}$ gradient in buffer. Fractions of $1 \mathrm{ml}$ were collected for analysis.

Determination of kinetic constants. $K_{\mathrm{m}}$ and $V_{\max }$ values for leu-pNA were determined from an Eadie-Hofstee plot generated from the initial reaction velocities obtained with leu-pNA concentrations between 0.1 and $3.0 \mathrm{mM}$ and $550 \mathrm{ng}$ of the purified LAP per assay. Each assay was carried out at $22^{\circ} \mathrm{C}$ in $20 \mathrm{~mm}$-Tris/ $\mathrm{HCl}(\mathrm{pH} \mathrm{8.0)}$ and the change in absorbance at $410 \mathrm{~nm}$ was monitored continuously using a Beckman DU-64 spectrophotometer for each substrate concentration for $5 \mathrm{~min}$.

Effects of inhibitors and influence of metal ions. Purified LAP was dialysed against $10 \mathrm{~mm}$-HEPES (8.0) to remove any contaminating cations and was then incubated separately with each inhibitor for $1 \mathrm{~h}$ at room temperature before residual enzyme activity was measured. Inhibitor concentrations were $3 \times 10^{-3} \mathrm{M}$ for DIFP and $1 \times 10^{-3} \mathrm{M}$ for the others (o-phenanthroline, $\mathrm{Na}_{2}$-EDTA, bestatin, NTA, EGTA, pepstatin, phosphoramidon, chymostatin, aprotinin and N-CBZ-PLGhydroxamate).

Various cations were added as chloride or acetate salts to the purified enzyme to assess their effect on enzyme activity. The ability of these cations to restore activity to enzyme previously inactivated with $o$ phenanthroline was also determined. Enzyme inactivated with $10 \mathrm{~mm}-$ $o$-phenanthroline was incubated with each cation preparation for $5 \mathrm{~min}$ at ambient temperature $\left(22^{\circ} \mathrm{C}\right)$ before measuring restored activity.

Effect of temperature and $p H$ on enzyme activity. Leu-pNA hydrolysis by purified LAP was assayed at different temperatures using a temperature-controlled cuvette holder attached to a Haake recirculating water bath. The cuvette was precalibrated using a temperature microprobe (YSI model 42SC tele-thermometer) to determine actual reaction temperatures. For each assay, the buffer was prewarmed for 5 min prior to addition of enzyme and substrate.

The effect of $\mathrm{pH}$ on leu-pNA hydrolysis was determined using the following buffers at $100 \mathrm{mM}$, supplemented with $10 \mathrm{mM}-\mathrm{CaCl}_{2}$ and 10 mM- $\mathrm{MgCl}_{2}$ : MES (pH 6.4-7.0); HEPES (pH 7.0-8.2); and Tris $/ \mathrm{HCl}$ (pH 8.0-8.8). The assays for optimal $\mathrm{pH}$ were carried out at ambient temperature (about $22^{\circ} \mathrm{C}$ ).

Reproducibility of results. Unless otherwise stated, all experiments were carried out at least in duplicate and the results given are means of 
those data. For purification, all steps were performed at least twice. The data given are for a representative purification scheme.

\section{Results and Discussion}

\section{Proteolytic activities of S. lividans}

Aretz et al. (1989) reported that S. lividans TK24 contained significant extracellular chymotrypsin-like and aminopeptidase proteinase activities, and we found that S. lividans 1326 contains significant azocasein hydrolysis activity (Gibb et al., 1989). Recently, a small, extracellular, neutral proteinase of $S$. lividans has been identified through cloning experiments (Lichenstein et al., 1992; Butler et al., 1992). Under normal conditions, however, this milk-hydrolysing proteinase has very little activity (Butler et al., 1992; Lampel et al., 1992). Additionally, a gene encoding an intracellular aminopeptidase $\mathbf{P}$ has been isolated from $S$. lividans and sequenced (Butler et al., 1991). Moreover, S. lividans has been used as a recipient for cloning proteinase genes from other streptomycetes because it lacks significant milk hydrolysis activity (Lampel et al., 1992). Thus, we have re-investigated the proteinase activities of $S$. lividans to clarify the types of proteinase activities present. As shown in Table 1, the major extracellular proteinase activity of $S$. lividans is a LAP activity. Azocasein hydrolysis activity was also observed, but no milk hydrolysis activity was found. S. lividans culture broths also displayed a low level of extracellular proline

\section{Table 1. Proteinolysis activities detected in cell extracts and culture supernatants of S. lividans 1326}

One unit of activity for hydrolysis of the following substrates is defined as: azocasein hydrolysis, increase in $A_{340}$ of $0.001 \mathrm{~A} \mathrm{~min}^{-1}$; $2 \%$ milk hydrolysis, decrease in $A_{580}$ of $0.001 \mathrm{Amin}^{-1}$; FAGLA hydrolysis, decrease in $A_{314}$ of $0.001 \mathrm{Amin}^{-1}$; TAME hydrolysis, increase in $A_{247}$ of $0.001 \mathrm{Amin}^{-1}$; and FALGPA hydrolysis, increase in $A_{345}$ of $0.001 \mathrm{Amin}^{-1}$. Units of activity for the $p$ nitroanilide substrates are reported as $\mu \mathrm{mol} \mathrm{min}^{-1}$. All data are means of at least duplicate samples.

\begin{tabular}{llcc}
\hline \hline & $\begin{array}{c}\text { Type of proteinase } \\
\text { Substrate } \\
\text { tested }\end{array}$ & $\begin{array}{c}\text { activity detected using } \\
\text { given substrate }\end{array}$ & $\begin{array}{c}\text { Proteinase activity } \\
\text { [units (mg protein) }\end{array}$ \\
\cline { 3 - 4 } & Intracellular Extracellular \\
\hline Azocasein & General & Not done & 12 \\
2\% Milk & General & 0 & 0 \\
BAPNA & Trypsin-like & 2 & 2 \\
SAAPF-pNA & Chymotrypsin-like & 3 & 3 \\
TAME & Esterase & 0 & 0 \\
FAGLA & Thermolysin-like & 0 & 0 \\
FALGPA & Collagenase & 0 & 0 \\
leu-pNA & Aminopeptidase (LAP) & 13 & 60 \\
pro-pNA & Aminopeptidase & 100 & 15 \\
ala-pNA & Aminopeptidase & 0 & 0 \\
lys-pNA & Aminopeptidase & 0 & 0 \\
gly-pNA & Aminopeptidase & 0 & 0 \\
\hline \hline
\end{tabular}

aminopeptidase activity. Significant intracellular proline aminopeptidase activity was observed, probably due to the aminopeptidase P (Butler et al., 1991).

Only background levels of proteinase activity on SAAPF-pNA (for chymotrypsin-like proteinases) or BAPNA (for trypsin-like proteinases) were found in the culture supernatants of $S$. lividans 1326 . Although the reported values are for $S$. lividans 1326 grown in MB medium, we also observed the same results when $S$. lividans 1326 was grown in TSB (trypticase soy broth) and GYE (glucose yeast extract) media (data not shown). Both the azocasein- and leu-pNA hydrolysing activities of $S$. lividans culture broths were inhibited by the metalloproteinase inhibitors $o$-phenanthroline and EGTA, but not by the serine proteinase inhibitors DIFP and PMSF (data not shown). These data suggest that if any enzymes possessing serine proteinase activity are being produced by $S$. lividans, they probably constitute a negligible portion of the total proteinase activity.

Additionally, we tested the culture broth of S. lividans with $\left[{ }^{3} \mathrm{H}\right] \mathrm{DIFP}$, followed by SDS-PAGE and autoradiography, to determine if serine proteinases might be present that were not detected with our enzyme assays. The concentrated S. lividans 1326 culture broth apparently does not have proteins that bind $\left[{ }^{3} \mathrm{H}\right] \mathrm{DIFP}$ (Fig. 1). On the other hand, proteins from the culture broths of Streptomyces sp. strain C5-A13, S. coelicolor $\mathrm{A} 3(2)$ and $S$. rimosus, organisms known to produce serine proteinases (Vinci, 1988; Gibb et al., 1989), strongly bound $\left[{ }^{3} \mathrm{H}\right] \mathrm{DIFP}$ (Fig. 1). These results suggest the absence of serine proteinases in the culture broth of $S$. lividans, since serine proteinases are known to bind strongly and irreversibly to DIFP. Additionally, the DNA of several streptomycetes has been probed with a mixed, consensus oligonucleotide probe deduced from the active site of serine proteinases (Vinci, 1988). Whereas DNA isolated from $S$. griseus, $S$. coelicolor, $S$. longisporus and Streptomyces sp. strain C5 contained several BamHI DNA fragments which hybridized strongly with the oligonucleotide probe at high stringencies, no DNA fragments from $S$. lividans hybridized strongly with the serine proteinase active site probe, even at lowered stringencies (Vinci, 1988). Taken altogether, the cumulative data indicate that $S$. lividans probably does not contain serine proteinases, or at least not significant serine proteinase activity, contrary to what was previously indicated (Aretz et al., 1989). Similarly, Streptomyces clavuligerus apparently has a neutral proteinase as its only major extracellular proteinase activity (Bascaran et al., 1990). This is rather unusual, however, since most streptomycetes produce multiple types of proteinases, including serine and metalloproteinase endopeptidases and amino- and carboxypeptidases (Narahashi, 1970; Pokorny et al., 1979; Chandrasekaran \& Dhar, 1987). 


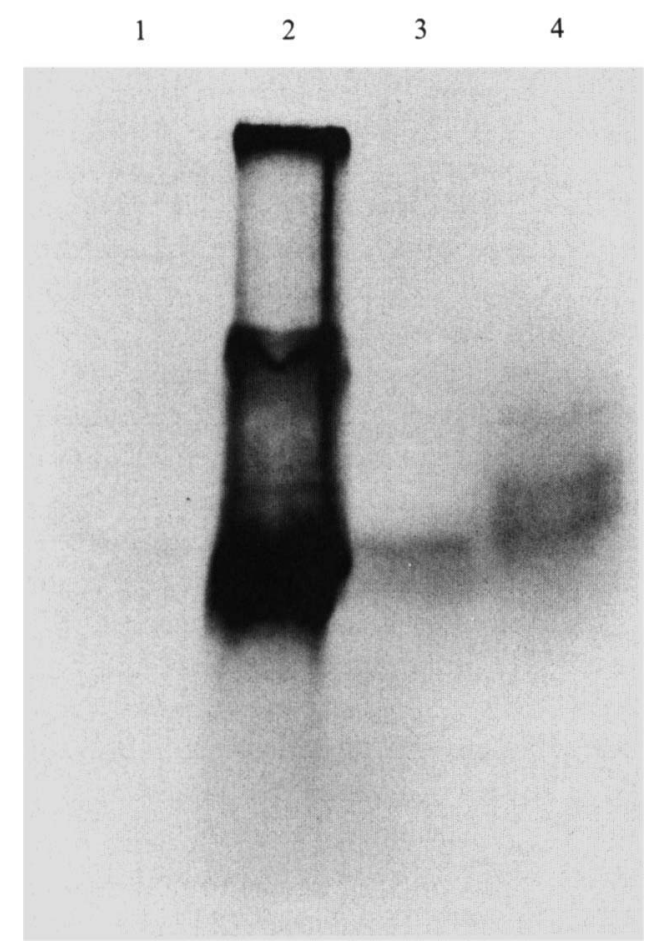

Fig. 1. Autoradiogram of concentrated culture broths of streptomycetes grown in GYE medium (Gibb et al., 1989) and treated with $\left[{ }^{3} \mathrm{H}\right] \mathrm{DIFP}$, which binds irreversibly to the active sites of serine proteinases, followed by separation of the proteins through $12 \%(\mathrm{w} / \mathrm{v}$, acrylamide) SDS-PAGE and autoradiography to show the $\left[{ }^{3} \mathrm{H}\right] \mathrm{DIFP}$-binding proteins. Approximately $10 \mu \mathrm{g}$ of protein were added per lane. Lanes: 1, S. lividans 1326 culture broth; 2, DIFP-binding proteins from Streptomyces sp. C5-A13 culture broth (Gibb et al., 1989); 3, DIFPbinding proteins from $S$. coelicolor A3(2) culture broth (Vinci, 1988); and 4, DIFP-binding proteins from $S$. rimosus culture broth (Pokorny et al., 1979).

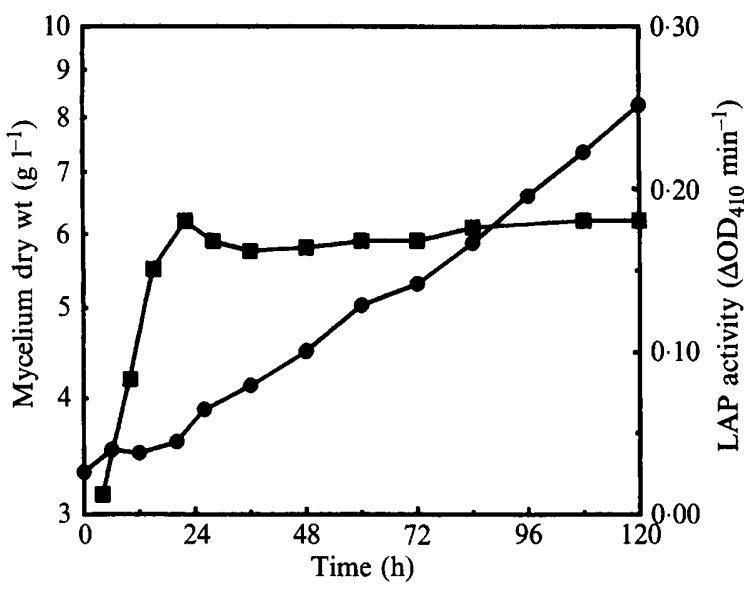

Fig. 2. Fermentation profile of $S$. lividans cultivated in MB medium. The dry weight of the mycelium ( $\boldsymbol{\square})$ and activity of LAP (O) are shown.

Many streptomycetes, most notably $S$. griseus, even produce multiple serine proteinases (Narahashi, 1970). Thus, it appears that $S$. lividans 1326 and $S$. clavuligerus
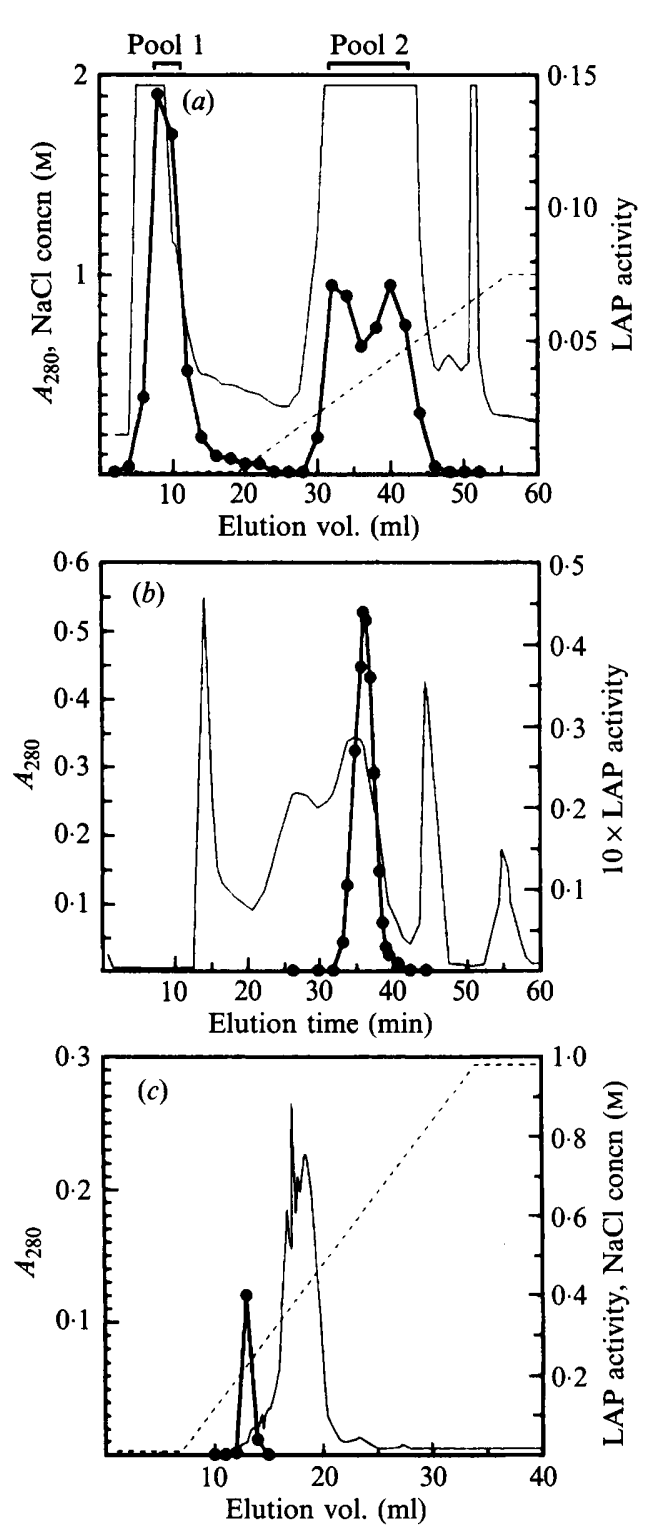

Fig. 3. Chromatographic steps used in the purification of LAP from $S$. lividans 1326 . For each step, protein $\left(A_{280} ;-\right)$ and enzyme activity (O) $\Delta A_{410} \mathrm{~min}^{-1}$ ) were measured as described in Methods. The dashed lines (-- ) in (a) and (c) indicate the $\mathrm{NaCl}$ gradients. (a) Mono-Q (HR 10/10) FPLC ion-exchange chromatography; the enzyme eluted in two broad peaks, the first in the wash-through (pool 1) and the second in a broad area between 250 and $550 \mathrm{~mm}-\mathrm{NaCl}$ (pool 2). (b) Superose- 6 (HR 10/30) FPLC gel-filtration chromatography; the enzyme from either pool 1 or pool 2 of $(a)$ eluted from the column at $35.5 \mathrm{~min}$. (c) Mono-Q (HR 5/5) FPLC ion-exchange chromatography; the enzyme from either pool 1 or pool 2 from $(a)$ eluted at $200 \mathrm{mM}-\mathrm{NaCl}$.

are unusual with respect to most streptomycetes in their complement of extracellular proteinases.

Fermentation profile and purification of $S$. lividans $L A P$

LAP activity was first detected after $18 \mathrm{~h}$ of culture growth but began to increase significantly only after the onset of stationary phase (Fig. 2), indicating that the 
Table 2. Scheme for the purification of the $M_{\mathrm{r}} 34000$ LAP from S. lividans culture supernatant

One unit of activity equals $1.0 \mu \mathrm{mol} p$-nitroaniline released $\mathrm{min}^{-1}$.

\begin{tabular}{lcccccc}
\hline \hline \multicolumn{1}{c}{$\begin{array}{c}\text { Purification } \\
\text { step }\end{array}$} & $\begin{array}{c}\text { Total } \\
\text { vol. } \\
(\mathrm{ml})\end{array}$ & $\begin{array}{c}\text { Total } \\
\text { protein } \\
\text { (mg) }\end{array}$ & $\begin{array}{c}\text { Total } \\
\text { activity } \\
\text { (units) }\end{array}$ & $\begin{array}{c}\text { Specific } \\
\text { activity } \\
\left.\text { (units mg }{ }^{-1}\right)\end{array}$ & $\begin{array}{c}\text { Purification } \\
\text { factor } \\
\text { (-fold) }\end{array}$ & $\begin{array}{c}\text { Percentage } \\
\text { recovery }\end{array}$ \\
\hline Cell-free broth & 2800 & 2296 & 253 & 0.11 & 1.0 & 100 \\
$>M_{\mathrm{r}}$ 10000 retentate & 200 & 430 & 94 & 0.22 & 2.0 & 37 \\
Lyophilization* & 30 & 425 & 119 & 0.28 & 2.5 & 47 \\
Mono-Q HR 10/10 & 8 & 53 & 7.6 & 0.14 & 1.3 & 3 \\
Superose-6 & 4 & 1.7 & 1.2 & 0.70 & 6.5 & 0.5 \\
Mono-Q HR 5/5 & 1 & 0.011 & 0.04 & 3.64 & 33 & 0.02 \\
\hline \hline
\end{tabular}

* Followed by resolubilization of the proteins in $20 \mathrm{~mm}$-Tris/HCl buffer (pH 8.0).

aminopeptidase is a post-growth associated activity. This was observed in a variety of fermentations using different media (data not shown). Therefore, fermentation broths from cultures $120 \mathrm{~h}$ old were used for purification of $S$. lividans LAP.

Several different protein purification procedures were used in attempts to purify the extracellular LAP from $S$. lividans 1326 . The major difficulty was the presence, in the supernatant fluids, of an uncharacterized brownpigmented substance that bound to the aminopeptidase, clogged several of the columns, and generally interfered with the purification procedures. The final purification scheme involved successive Mono-Q and Superose-6 chromatography steps. After lyophilization to concentrate the protein, the resuspended mixture was fractionated into two large pools using a Mono-Q HR $10 / 10$ column. Two peaks of LAP activity were obtained by this step, both containing some pigment. The first peak of activity eluted in the wash-through and the second eluted in a broad region from 250 to about $550 \mathrm{~mm}-\mathrm{NaCl}$ (Fig. 3a). A 2-fold loss in the purification of the enzyme was noted at this step (Table 2). LAP concentrated from the active fractions of pool 1 , however, eluted only in a sharp peak at 200 to $250 \mathrm{~mm}$ on the second Mono-Q 5/5 column (data not shown). Thus, it appears that the Mono-Q 10/10 column was apparently 'overloaded'. Since the column was designated to handle considerably more protein than was loaded, we surmise that the 'overloading effect' was due to interaction of the column and proteins with the interfering brown pigment.

Superose- 6 gel-filtration chromatography of pool 2 from the large Mono-Q resin at about $250 \mathrm{~mm}-\mathrm{NaCl}$ helped in removing more of the brown pigment from the enzyme preparation (Fig. $3 b$ ), while offering an additional 5-fold purification (Table 2). The protein concentrated from the Superose- 6 step was loaded onto a smaller Mono-Q ion exchanger (HR 5/5), which gave a further 5-fold purification of the enzyme (Table 2). All the pigment was separated from the active LAP which eluted at approximately $200 \mathrm{~mm}-\mathrm{NaCl}$ (Fig. $3 c$ ), while the pigment eluted from the column at about $550 \mathrm{~mm}$ $\mathrm{NaCl}$ in this step. While this protocol resulted in a 33fold final purification of the LAP, only $0.02 \%$ of the active enzyme could be recovered (Table 2). This tremendous loss was largely due to the problems associated with the contaminating brown pigment.

SDS-PAGE analysis of the most active fraction from this Mono-Q step revealed a homogeneous polypeptide of $M_{\mathrm{r}} 34000$ (Fig. 4). This same protein eluted from a calibrated Superose- 6 column at $35.5 \mathrm{~min}$, which corresponds to an $M_{\mathrm{r}}$ of 19000 (data not shown). This Superose- 6 elution profile occurred even in the presence of $0.15 \mathrm{M}-\mathrm{NaCl}$ and was reproducible with several different preparations of partially and completely purified protein. The large difference in calculated $M_{\mathrm{r}}$ from SDS-PAGE and Superose-6 may result from an incomplete protein denaturation or binding of SDS, or an atypical retardation of the enzyme on the gel-filtration support column (Superose-6). Interestingly, the two aminopeptidases from $S$. griseus displayed nearly identical anomalous elution profiles from Superose- 12 gel filtration as compared to their $M_{\mathrm{r}}$ values determined from SDS-PAGE, as did S. lividans LAP (Spungin \& Blumberg, 1989).

LAP purified from pool 1 of the Mono-Q HR 10/10 column also eluted from Superose- 6 at $35.5 \mathrm{~min}$ and from Mono-Q $\mathrm{HR} 5 / 5$ at $200 \mathrm{~mm}-\mathrm{NaCl}$ (data not shown). The resulting preparation had a major protein of $M_{\mathrm{r}} 34000$ (by SDS-PAGE), but LAP purified from pool 1 was not homogeneous.

\section{Properties of S. lividans LAP}

The purified LAP had a specific activity on leu-pNA of $3.6 \mu \mathrm{mol} \mathrm{min}^{-1}$ (mg protein) $)^{-1}$. No other hydrolysis activity was observed on any other substrates tested, 


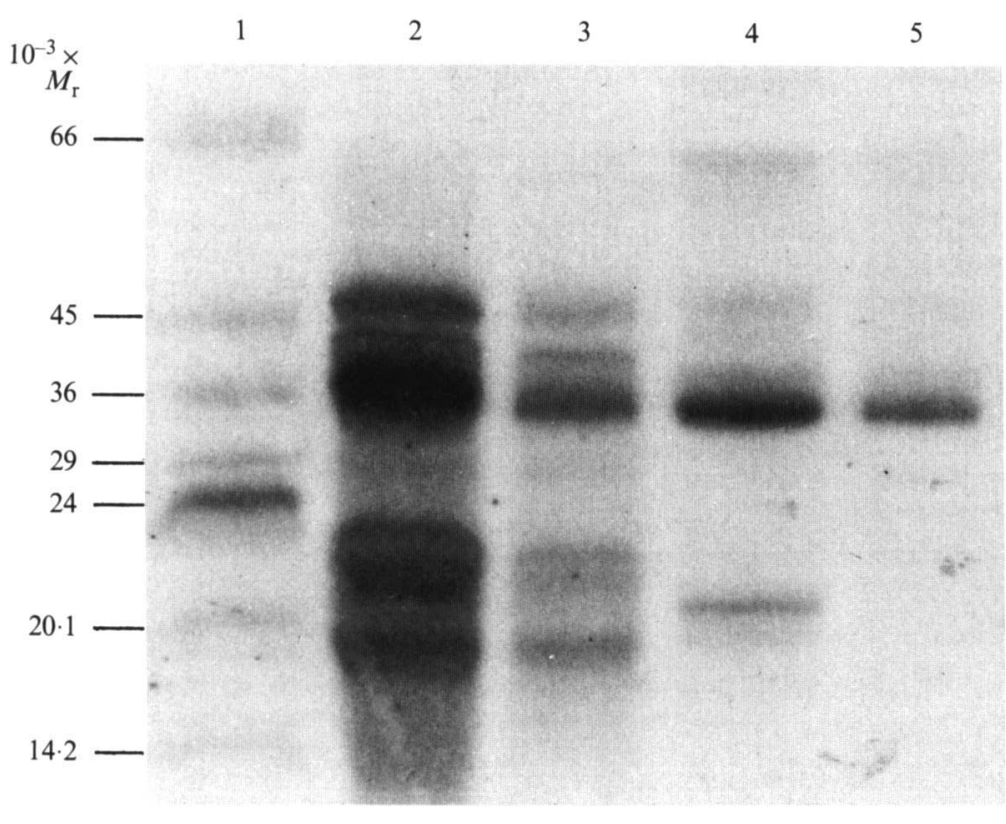

Fig. 4. Determination of $M_{\mathrm{r}}$ by SDS-PAGE of the purified $S$. lividans LAP. Lane 1, Size standards; bovine serum albumin $\left(M_{\mathrm{r}} 66000\right)$, egg albumin (45000), glyceraldehyde 3-phosphate dehydrogenase (subunit: 36000), carbonic anhydrase (29000), bovine trypsinogen (24000), soybean trypsin inhibitor $(20100)$ and bovine $\alpha$-lactalbumin (14200); lane 2, proteins from the $>M_{\mathrm{r}}$ 10000 ultrafiltration step; lane 3, proteins from the large Mono Q (10/10) step; lane 4, proteins from the Superose-6 step; and lane 5, purified $M_{\mathrm{r}}$ 34000 LAP from the small Mono Q (5/5) step. Proteins in the gel were stained with Commassie brilliant blue-R.
Table 3. Effect of divalent cations on S. lividans LAP activity

The purified enzyme was first dialysed against $100 \mathrm{~mm}$-HEPES $(\mathrm{pH} 8.0)$ for $24 \mathrm{~h}$ at $4{ }^{\circ} \mathrm{C}$. Divalent cations were added to a final concentration of $10 \mathrm{~mm}$ and incubated with the LAP at $37^{\circ} \mathrm{C}$ for $5 \mathrm{~min}$ before assaying for activity against leu-pNA. The specific activity of the dialysed enzyme (control'value) to which no metal was added was $3.64 \mu \mathrm{mol} \mathrm{min}^{-1} \mathrm{mg}^{-1}$. The values reported are means of duplicate assays.

\begin{tabular}{lc}
\hline \hline $\begin{array}{c}\text { Divalent cation } \\
\text { (added as:) }\end{array}$ & $\begin{array}{c}\text { Percentage of } \\
\text { control activity }\end{array}$ \\
\hline Control (no metal added) & 100 \\
$\mathrm{CoCl}_{2}$ & 177 \\
$\mathrm{Ca}\left(\mathrm{CH}_{3} \mathrm{COO}\right)_{2}$ & 100 \\
$\mathrm{Zn}\left(\mathrm{CH}_{3} \mathrm{COO}\right)_{2}$ & 100 \\
$\mathrm{SrCl}_{2}$ & 100 \\
$\mathrm{NiCl}_{2}$ & 83 \\
$\mathrm{BaCl}_{2}$ & 77 \\
$\mathrm{MnCl}_{2}$ & 73 \\
$\mathrm{MgCl}_{2}$ & 70 \\
$\mathrm{StCl}_{2}$ & 39 \\
$\mathrm{CdCl}_{2}$ & 24 \\
$\mathrm{CuCl}_{2}$ & 13 \\
$\mathrm{CrCl}_{2}$ & 7 \\
$\mathrm{HgCl}_{2}$ & 6 \\
\hline \hline
\end{tabular}

including $2 \%(\mathrm{w} / \mathrm{v})$ milk, azocasein, BAPNA, SAAPFpNA, pro-pNA, gly-pNA, ala-pNA or lys-pNA (data not shown).

The effect of various metals on the activity of extensively dialysed, purified $S$. lividans LAP is shown in Table 3. Dialysed S. lividans LAP retains $100 \%$ of the activity of undialysed enzyme, indicating that the metal required for activity of $S$. lividans LAP (probably $\mathrm{Zn}^{2+}$ ) was not removed from the enzyme by dialysis alone.

\section{Table 4. Effects of inhibitors on S. lividans LAP}

All inhibitors except DIPF were at $10 \mathrm{~mm}$ final concentration. DIPF was at $3.0 \mathrm{~mm}$ final concentration. Activity was measured against leu-pNA as the substrate. Activity of the untreated enzyme was $3.6 \mu \mathrm{mol} \mathrm{min} \mathrm{mg}^{-1} \mathrm{mg}^{-1}$ and was taken as $100 \%$. The values reported are means of duplicate assays.

\begin{tabular}{lc}
\hline \multicolumn{1}{c}{ Inhibitor } & $\begin{array}{c}\text { Percentage } \\
\text { inhibition }\end{array}$ \\
\hline o-Phenanthroline & 93 \\
$\mathrm{Na}_{2}$-EDTA & 77 \\
Bestatin & 64 \\
NTA & 60 \\
EGTA & 46 \\
Pepstatin & 0 \\
Phosphoramidon & 0 \\
Chymostatin & 0 \\
Aprotinin & 0 \\
N-CBZ-PLG-hydroxamate & 0 \\
DIFP & 0 \\
\hline
\end{tabular}

Treatment with $\mathrm{Co}^{2+}$ stimulated activity of the dialysed enzyme, while treatment with $\mathrm{Ca}^{2+}, \mathrm{Zn}^{2+}$ or $\mathrm{Sr}^{\mathrm{r}+}$ yielded the same activity as untreated enzyme. The stimulation of aminopeptidase activity by $\mathrm{Co}^{2+}$ has been observed previously (Wagner et al., 1979; Nakamura et al., 1984). All of the other divalent metals or metalloids tested inhibited LAP activity to various degrees.

$S$. lividans LAP is sensitive to chelating agents and bestatin, but not to known inhibitors of thermolysin-like metalloproteinases, serine proteinases or acid proteinases (Table 4). o-Phenanthroline was the most effective inhibitor of $S$. lividans LAP. After treatment with $o$ phenanthroline, however, activity was reproducibly 
restored $100 \%$ by addition of excess $\mathrm{Co}^{2+}$ and was $70 \%$ restored by addition of excess $\mathrm{Zn}^{2+}$ (data not shown). Excess $\mathrm{Ca}^{2+}$ did not restore activity of $o$-phenanthrolinetreated $S$. lividans LAP, indicating that it is not required for activity (data not shown). Enzymic activity of LAP diminished significantly, however, when the enzyme was stored at $4{ }^{\circ} \mathrm{C}$ in the absence of $\mathrm{Ca}^{2+}$ for more than $7 \mathrm{~d}$. On the other hand, enzyme preparations stored in buffers containing $\mathrm{Ca}^{2+}$ did not lose significant leu-pNAhydrolysing activity even after a month at $4{ }^{\circ} \mathrm{C}$. The combined data indicate that $\mathrm{Ca}^{2+}$ is required for stability of $S$. lividans LAP but is not necessary for its activity against leu-pNA.

The $K_{\mathrm{m}}$ and $V_{\max }$ values for leu-pNA hydrolysis by $S$. lividans LAP $\left(\mathrm{pH} 8.0,22^{\circ} \mathrm{C}\right)$ are $3.0 \times 10^{-4} \mathrm{M}$ and $4.24 \mu \mathrm{mol} \mathrm{min}{ }^{-1} \mathrm{mg}^{-1}$, respectively (data not shown). $K_{\text {cat }}$ for hydrolysis of leu-pNA is $2 \cdot 3 \mathrm{~s}^{-1}$, and $K_{\text {cat }} / K_{\mathrm{m}}$ is $7.7 \times 10^{3}$. These values are similar to those obtained by Vitale et al. (1986) for the $S$. rimosus LAP.

The optimum temperature for activity of $S$. lividans LAP is $46^{\circ} \mathrm{C}$, with $85 \%$ of the activity remaining at $36^{\circ} \mathrm{C}$ and $55^{\circ} \mathrm{C}$, and $45 \%$ of the activity remaining at $20^{\circ} \mathrm{C}$ and $62{ }^{\circ} \mathrm{C}$ (data not shown). The optimum $\mathrm{pH}$ for activity is 8.0 , with about $70 \%$ of the activity remaining at $\mathrm{pH}$ values of 7.2 and 8.2 . Less than $50 \%$ of the maximal activity was obtained at $\mathrm{pH}$ values of 7.0 and 8.4 (data not shown).

Since purified $S$. lividans LAP is not inhibited by DIFP, aprotinin or chymostatin, it is not a serine proteinase. This enzyme is also not inhibited by N-CBZPLG-hydroxamate and does not hydrolyse FALGPA, indicating that it does not have collagenase activity. The inability of the $S$. lividans LAP to hydrolyse FAGLA and the inability of phosphoramidon to inhibit leu-pNA hydrolysis indicate that the enzyme does not belong to the thermolysin-family of neutral proteinases. Nevertheless, $S$. lividans LAP was inhibited by $o$-phenanthroline, $\mathrm{Na}_{2}$-EDTA, NTA and EGTA, indicating that it is a metalloproteinase. Furthermore, the enzyme was partially inhibited by bestatin, a known inhibitor of aminopeptidases (Vitale et al., 1986). The combined data indicate that $S$. lividans LAP is a metallo-enzyme, produced during stationary phase, that has a rather narrow range of substrate specificities.

Comparison of S. lividans LAP with other streptomycete LAPS

Morihara (1967) demonstrated the presence of a LAP from Streptomyces fradiae that requires $\mathrm{Ca}^{2+}$ for its activity. Uwajima et al. (1973) purified a $M_{\mathrm{r}} 19000$ LAP from culture supernatants of Streptomyces peptidofaciens that was inhibited by EDTA and $o$-phenanthroline. Their EDTA-inactivated enzyme was successfully reactivated by addition of $\mathrm{Ca}^{2+}$, indicating a probable requirement of $\mathrm{Ca}^{2+}$ for enzymic activity. Another $\mathrm{Ca}^{2+}$-requiring LAP was purified from Streptomyces sp. 771 by Krest'yanova et al. (1983). Vitale et al. (1986) purified an extracellular LAP from $S$. rimosus and characterized its properties in detail. This enzyme is stable over a broad $\mathrm{pH}$ range, has an $M_{\mathrm{r}}$ of 27000 , a pI of $7 \cdot 3$, requires $\mathrm{Ca}^{2+}$ for its LAP activity, and is inhibited by $\mathrm{Zn}^{2+}$. Two aminopeptidases (API and APII) purified from $S$. griseus were originally shown to require $\mathrm{Ca}^{2+}$ for their enzymic activity (Vosbeck et al., 1973). More recently, however, these LAPs were proved to be $\mathrm{Zn}^{2+}$-containing enzymes that are activated by calcium (Spungin \& Blumberg, 1989). Our data suggest that the $M_{\mathrm{r}} 34000$ LAP from $S$. lividans is a zinc metalloproteinase which is stabilized, but not necessarily activated, by calcium. The $S$. lividans LAP, therefore, is very different from the LAPs of $S$. peptidofaciens, $S$. fradiae and $S$. rimosus. On the other hand, $S$. lividans LAP appears to be very similar, but apparently not identical, to the $S$. griseus LAPs, API and APII.

We thank Don Ordaz and the Ohio State University Fermentation Facility for assistance with the fermentations. We also thank Dr Kathleen Kendrick and her laboratory group for use of their FPLC during these investigations.

\section{References}

Aretz, W., Koller, K. P. \& Riess, G. (1989). Proteolytic enzymes from recombinant Streptomyces lividans TK24. FEMS Microbiology Letters 65, 31-36.

Bascaran, V., Hardisson, C. \& Braña, A. (1990). Regulation of extracellular protease production in Streptomyces clavuligerus. Applied Microbiology and Biotechnology 34, 208-213.

Bender, E., Vogel, R., Koller, K.-P. \& ENGles, J. (1990). Synthesis and secretion of hirudin by Streptomyces lividans. Journal of Bacteriology 34, 203-207.

BradFord, M. M. (1976). A rapid and sensitive method for quantitation of microgram quantities of protein utilizing the principle of protein-dye binding. Analytical Biochemistry 72, 248-254.

Butler, M. J., Bergeron, A., Krygsman, P., SOOstmeyer, G., Zimny, T. \& MALEK, L. T. (1991). Cloning and characterization of an aminopeptidase $\mathbf{P}$ gene from $S$. lividans 66. Abstracts, 1991 International Symposium on Biology of Actinomycetes, P1-123.

Butler, M. J., Davey, C. C., Krygsman, P., Walczyk, E. \& Malek, L. T. (1992). Cloning of genetic loci involved in endoprotease activity in Streptomyces lividans 66: a novel neutral protease gene with an adjacent divergent putative regulatory gene. Canadian Journal of Microbiology 38, 912-920.

Chandrasekaran, S. \& Dhar, S. C. (1987). Multiple proteases from Streptomyces moderatus. I. Isolation and purification of five extracellular proteases. Archives of Biochemistry and Biophysics 257, 395-401.

Colletta, P. L. \& Miller, P. G. G. (1986). The extracellular proteases of Myxococcus xanthus. FEMS Microbiology Letters 37, 203-207.

Delmar, E. G., Largman, C., Brodrick, J.W. \& Geokas, M. C. (1979). A sensitive new substrate for chymotrypsin. Analytical Biochemistry 99, 316-320.

Dreyfuss, O., Adam, S. A. \& Choi, Y. D. (1984). Physical change in cytoplasmic messenger ribonucleoproteins in cells treated with inhibitors of mRNA transcription. Molecular and Cell Biology 4, 415-423. 
ERlanger, B. F., Kokowski, N. \& Cohen, W. (1961). The preparation and properties of two new chromogenic substrates of trypsin. Archives of Biochemistry and Biophysics 95, 271-278.

FEDER, J. (1968). A spectrophotometric assay for neutral protease. Biochemical and Biophysical Research Communications 32, 326-332.

GibB, G. D., Ordaz, D. E. \& STROHL, W. R. (1989). Overproduction of extracellular proteinase activity by Streptomyces C5-A13 in fedbatch fermentations. Applied Microbiology and Biotechnology 31, 119-124.

Krest'yanova, I. N., Vasil'eVa, L. I., Bartoshevich, I. E., AKParov, VKH. \& NAKHAPETIAN, L. A. (1983). Isoelectric focusing of a preparation of proteolytic enzymes from Streptomyces 771. Prikladnaya Biokhimyia i Mikrobiologiya 19, 217-225. (English translation: Prikladnaya Biokhimiya i Mikrobiologiya 19, 175-183).

Lampel, J. S., APHale, J. S., LAmpel, K. A. \& Strohl, W. R. (1992). Cloning and sequencing of a gene encoding a novel extracellular neutral proteinase from Streptomyces sp. strain C5 and expression of the gene in Streptomyces lividans 1326. Journal of Bacteriology 174, $2797-2808$.

Lichenstein, H., Brawner, M. E., Miles, L. M., Myers, C. A., YounG, P. R., Simon, P. L. \& ECKARDT, T. (1988). Secretion of interleukin- $1 \beta$ and Escherichia coli galactokinase by Streptomyces lividans. Journal of Bacteriology 170, 3924-3929.

Lichenstein, H. S., Busse, L. A., Smith, G. A., Narhi, L. O., MCGinley, M. O., RohDE, M. F., Katzowitz, J. L. \& ZuKowski, M. M. (1992). Cloning and characterization of a gene encoding extracellular metalloprotease from Streptomyces lividans. Gene 111, 125-130.

Malek, L. T., Soostmeyer, G., Davey, C., Krygsman, P., Compton, J., Gray, J., ZimnY, T. \& StewarT, D. (1990). Secretion of granulocyte macrophage-colony stimulating factor (GM-CSF) in Streptomyces lividans. Journal of Cell Biochemistry, Supplement 14A, 127.

Morihara, K., OKa, T. \& Tsuzuki, H. (1967). Multiple proteolytic enzymes of Streptomyces fradiae. Biochimica et Biophyisca Acta 139, 382-387.
Nakamura, T., Kiuchi, N. \& Fujiyama, S. (1984). Purification and partial characterization of leucine aminopeptidase from Actinomyces viscosus. Matsumoto Shigaku 10, 130-135.

Narahashi, Y. (1970). Pronase. Methods in Enzymology 19, 651-664.

Pokorny, M., Vitale, LJ., Turk, V., Renko, M. \& Zuvanic, J. (1979). Streptomyces rimosus extracellular proteinases. 1. Characterization and evaluation of various crude preparations. European Journal of Applied Microbiology and Biotechnology 8, 81-90.

Roberts, D. V. \& Elmore, D. T. (1974). Kinetics and mechanism of catalysis by proteolytic enzymes. Biochemical Journal 141, 545-554.

Spungin, A. \& BlumberG, S. (1989). Streptomyces griseus aminopeptidase is a calcium-activated zinc metalloprotein. Purification and properties of the enzyme. European Journal of Biochemistry 183, $471-477$.

Taguchi, S., Kumagal, I., Nakayama, J., Suzuki, A. \& Miura, K. (1989). Efficient extracellular expression of a foreign protein in Streptomyces using secretory proteinase inhibitor (SSI) gene fusions. Bio/Technology 7, 1063-1066.

Uwajima, T., Yoshikawa, N. \& Terada, O. (1973). A crystalline aminopeptidase from Streptomyces peptidofaciens: physio-chemical properties and characteristics as a Ca-metalloprotease. Agricultural and Biological Chemistry 37, 2727-2733.

VINCI, V. A. (1988). Biochemical and genetic analysis of serine proteases of Streptomyces spp. PhD Dissertation, The Ohio State University, Columbus, USA.

Vitale, LJ., Renko, M., Lenarcic, B., Turk, V. \& Pokorny, M. (1986). Streptomcyes rimosus extracellular proteinases. 3. Isolation and characterization of leucine aminopeptidase. Applied Microbiology and Biotechnology 23, 449-455.

Vosbeck, K. D., Chow, K. \& AwaD, W. M. (1973). The proteolytic enzymes of the K-1 strain of Streptomyces griseus obtained from a commercial preparation (pronase). Journal of Biological Chemistry 248, 6029-6034.

Wagner, F. W., Ray, L. E., Ajabnoor, M. A., Ziemba, P. L. \& Hall, R. L. (1979). Bacillus subtilis aminopeptidase: purification, characterization and some enzymatic properties. Archives of Biochemistry and Biophysics 197, 63-72. 